\title{
Lithium Nitrate Induced Biochemical Modifications in catla catla upon Short Term Exposure
}

\author{
S. Jagadeep Chandra', Naganagouda. V. Kote ${ }^{2}$, S.Sandya ${ }^{3}$, Sharath Chandra SP ${ }^{4, *}$
}

\section{S. Jagadeep Chandra', Naganagouda. V. Kote ${ }^{2}$ S.Sandya ${ }^{3}$, Sharath Chandra $\mathrm{SP}^{4, *}$}

'Department of Microbiology, Faculty of Life Sciences, JSS academy of higher education and research, Mysuru, India. ${ }^{2}$ Department of Biochemistry, Maharani's Science College for Women, Bengaluru, INDIA.

${ }^{3}$ Department of Inorganic and Physical Chemistry, Indian Institute of Science, Bangalore, INDIA.

${ }^{4}$ Department of Biochemistry, Government Science College, Hassan, INDIA.

\section{Correspondence}

\section{Sharath Chandra SP}

Department of Biochemistry, Government Science College, Hassan, Karnataka, INDIA.

Phone no: +919902354387

E-mail: biosharath123@gmail.com

History

- Submission Date: 16-07-2020;

- Review completed: 05-09-2020;

- Accepted Date: 14-09-2020.

DOI : 10.5530/pj.2020.12.230

Article Available online

http://www.phcogj.com/v12/i6s

\section{Copyright}

(C) 2020 Phcogi.Com. This is an openaccess article distributed under the terms of the Creative Commons Attribution 4.0 International license.

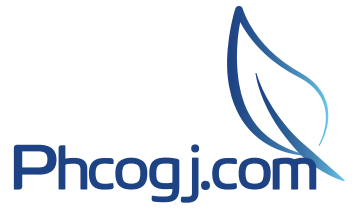

\begin{abstract}
Background: Alkali metals such as lithium nitrate due to its properties have found their application in industries. However, reports of acute toxicological impact of lithium nitrate on aquatic animals are largely not available in the literature. Objective: With this interest, we have assessed the impact of $\mathrm{LiNO}_{3}$ on Catla catla, a freshwater fish widely consumed. Materials and Methods: In this study, $\mathrm{LC}_{50}$ of $\mathrm{LiNO}_{3}$ was determined to be $5 \mathrm{ppm}$, for $24 \mathrm{~h}$. Following this, $1 / 10^{\text {th }}$ of the $\mathrm{LC}_{50}$ levels of $\mathrm{LiNO}_{3}(0.5 \mathrm{ppm})$ was chosen for acute investigation of $96 \mathrm{~h}$. Results: The results demonstrated increase in serum aspartate transaminase (AST), alanine transaminase (ALT) and lactate dehydrogenase (LDH) in treated fish. Further examinations disclosed changes in antioxidant enzyme systems with remarkable changes in the serum catalase (CAT) and superoxide dismutase (SOD) contents, with elevation in malondialdehyde (MDA). The investigation found increased glutamate levels in the brain tissue of treated groups, demonstrating tissue damage. Conclusion: The study underlines the toxicological impact of $\mathrm{LiNO}_{3}$ and role of certain potential biomarkers which determine the impact of these toxicants in aquatic environment.

Key words: Biological, Catla, Glutamate, Lithium, Oxidative stress.
\end{abstract}

\section{INTRODUCTION}

Discharge and presence of chemicals in the environment due to their multipurpose properties has given rise to contamination in several ecosystems. These chemicals and their derivatives have everlasting toxicological influence on the ecosystem..$^{1-3}$ The presence of these chemicals/ metals results in irreversible damage in cells, which in-turn affects the whole organ or tissue. ${ }^{4}$ The pattern of these chemicals to segregate in the aquatic environment, fish in precise, have remarkable deleterious influence on the food chain. Human beings, consume fish as source of food, are a chief participant in the food chain, thus a worrying issue in health of human population. The role of chemicals in the tissue of fish is based on numerous parameters like proximity of fish to the chemical effluents, metabolism, and climate and membrane transport capacity. ${ }^{5}$

Lithium nitrate is an alkali metal nitrate which is in organic in nature. The largest oxoanion in this compound is nitrate. It is an oxidizing molecule used in the fireworks industries. Toxicity of metals like mercury, lead, arsenic, cadmium and other metals in fish models are well known and established, very little is known about the acute toxicity of lithium and in particular lithium nitrate is available in the literature. With this interest we selected freshwater carp Catla catla for the assessment of acute toxicity of lithium nitrate.

$\mathrm{LC}_{50}$ indicates of the level of resistance of a test model to xenobiotics. ${ }^{6}$ Biochemical understanding of treated fish demonstrates the degree of damage imposed by pollutants. Toxin/Chemical induced stress facilitates oxidative damage generating reactive oxygen species (ROS), accompanied by diminution of natural antioxidants. Measurement of antioxidant enzymes namely superoxide dismutase and catalase reflects the biochemical modifications on toxicity. Change in levels of glutamate, a neurotransmitter, is a reminder of neurons being vulnerable to free radicals, ensuing neurotransmitter changes leading to neurodegenerative disorders. ${ }^{7}$

\section{MATERIALS AND METHODS}

\section{Animals}

Indian freshwater juvenile carp, Catla catla were maintained in flow through system in dechlorinated water for 15 days. Water quality optimized to be 31.3 $\pm 2.8 \mathrm{CaCo}_{3} \mathrm{mg} / \mathrm{L}$ of hardness and $\mathrm{pH}$ of $7.2 \pm 0.5$, at $23 \pm 1{ }^{\circ} \mathrm{C}$. For assessment, fishes were separated into three groups of 50 each which were maintained in $90 \mathrm{~L}$ aquarium. All the fishes were maintained in accordance to ethical committee recommendations.

\section{Lithium nitrate $\left(\mathrm{LiNO}_{3}\right)$ sample optimization}

20g/L of LiNO3 solution was prepared in double distilled water. The fish groups were treated with $\mathrm{LiNO}_{3}$ for short duration of $96 \mathrm{hr}$. Dose of $0.5 \mathrm{mg} / \mathrm{L}$ depending on $1 / 10^{\text {th }}$ of $\mathrm{LC}_{50}$ concentration $(5 \mathrm{mg} / \mathrm{L})$ was mixed in $90 \mathrm{~L}$ aquariums housing 50 fishes each. Every $24 \mathrm{~h}$ the water was freshly added and solution of $\mathrm{LiNO}_{3}$ was. A group of 50 control fishes were also kept under the comparable physical conditions as of treated group. $24 \mathrm{~h}$ before sacrifice food was withdrawn; to facilitate postprandial changes. Nil mortality was reported during the whole $96 \mathrm{~h}$ exposure to lithium nitrate

Cite this article: Chandra SJ, Kote NV, Sandya S, Sharath CSP. Lithium Nitrate Induced Biochemical Modifications in catla catla upon Short Term Exposure. Pharmacogn J. 2020;12(6) Suppl:1705-9. 


\section{Collection of samples}

Cardiac puncture was performed to take blood from the fishes. The samples for biochemical assessment were maintained in EDTA vials. The brain tissue for analysis of glutamate was quickly dissected and placed in ice for studies. The brain tissue during analysis was homogenized with cold Tris buffer saline $(10 \mathrm{mM}$ Tris- $\mathrm{HCl}, 10 \mathrm{mM}$ sucrose, $0.7 \% \mathrm{NaCl}$, $0.1 \mathrm{mM}$ EDTA of $\mathrm{pH} 7.2$ ) at $4^{\circ} \mathrm{C}$. The sample was further centrifuged and the supernatant was selected for further investigation.

\section{Biochemical parameter measurement}

Plasma glucose content was measured by reaction mixture of $0.1 \mathrm{~mL}$ of plasma and $4 \mathrm{ml}$ of o-toluidine. ${ }^{8}$ and was than incubated for $10 \mathrm{~min}$ on a boiling water bath. The absorbance was read at $630 \mathrm{~nm}$ in a UV spectrophotometer. The glucose levels were read as $\mathrm{mg} / \mathrm{dL}$. Plasma protein content was analyzed by lowry's method. ${ }^{9} 4 \mathrm{ml}$ of Lowry reagent, $100 \mu \mathrm{l}$ of plasma and $900 \mu \mathrm{l}$ of double distilled water was mixed well and incubated for $10 \mathrm{~min}$ at room temperature, to this mixture FC $(0.5 \mathrm{ml})$ reagent was mixed and incubated at room temperature for 20 min. The sample was then measured at $720 \mathrm{~nm}$ and $\mathrm{read}$ as $\mu \mathrm{g} / \mathrm{ml}$.

\section{Analysis of serum transaminases}

Serum L aspartate aminotransferase (L-AST) and L-alanine aminotransferase (L-ALT) activities were reported by colorimetric method $^{10}$ and enzyme activity was represented as IU/L. Lactate dehydrogenase (LDH) was analyzed by Anon (1984) and activity was represented as IU/L.

\section{Oxidative stress markers and glutamate analysis}

Superoxide dismutase (SOD) was measured ${ }^{11}$ by superoxide led nitrite formation inhibition from hydroxylamine hydrochloride and the absorbance was measured at $540 \mathrm{~nm}$ and activity was represented as $\mathrm{U} / \mathrm{mg}$ of protein. Catalase activity was analyzed depending on the generation of stable hydrogen peroxide and ammonium molybdate complex. The absorbance was read at $405 \mathrm{~nm}$ and represented as $\mathrm{U} /$ mg. ${ }^{12}$ Lipid peroxidation was investigated with malondialdehyde (MDA) as standard. ${ }^{13}$ The sample was quantified at $535 \mathrm{~nm}$ and read as $\mathrm{nmol} / \mathrm{mg}$. Glutamate content was analyzed by multiple development of paper chromatography. ${ }^{14}$ The absorbance was measured at $515 \mathrm{~nm}$. The concentration is represented as $\mu \mathrm{mol} / \mathrm{g}$ of glutamate.

\section{Statistical analysis}

The data were statistically evaluated and expressed as Mean \pm SE. In experiments, the pattern of statistical significance was set as $P<0.05$. The significance was determined by Student's $t$-test using MS-Excel.

\section{RESULTS AND DISCUSSION}

This investigation reports the impact of $\mathrm{LiNO}_{3}$ exposure on the biochemistry of freshwater fish $C$ catla. The fish were separated into treated $\left(0.5 \mathrm{ppm}\right.$ of $\left.\mathrm{LiNO}_{3}\right)$ and non-treated groups and observed for 24, 48, 72 and $96 \mathrm{~h}$. The plasma assessment of $\mathrm{LiNO}_{3}$ treated C. catla shows remarkable rise in glucose levels (Table 1) ton all 4 days of exposure, however main observation of $4.23 \pm 0.29 / 28.11 \pm 0.16$ was found on the $4^{\text {th }}$ day. This can be associated to stress culminating in hyperglycemia. Similar findings were made and related to the changes in glucose metabolism, because of glycogenolysis in fish. Elevation in glucose levels upon chemical exposure have been reported due to glucose synthesis from amino acids of extra hepatic tissue. Many studies correlated elevation in plasma glucose levels to generation of catecholamines and glucocorticoids from fish adrenal glands during stress. $^{15}$

Decline in plasma protein level (Table 1) was seen in treated groups on the $4^{\text {th }}$ day $(15.32 \pm 0.38 / 11.68 \pm 0.12)$. The reduced protein levels are interrelated to binding of chemicals to blood and tissue proteins, causing tissue injury from oxidative stress arising from free radicals.

This may also cause modification in physicochemical properties which is evident in conformational change of protein structure, thus causing decline in protein levels in the current study. Toxicity due to chemicals can also be attributed for decline in protein levels, also inhibiting transcription and translational mechanism. ${ }^{16}$

The detection of clinically significant enzymes such as alanine transaminase (ALT/GPT) and aspartate transaminase (AST/GOT) are evaluated for any tissue damage. Identification of these biomarkers is coupled with enzyme inhibition in metabolic mechanisms due exertion of stress. In this investigation, a noted elevation in AST and ALT level was seen in treated groups in comparison to control. This is due to tissue and organ damage by exposure to $\mathrm{LiNO}_{3}$ and similar xenobiotics. ${ }^{17}$ This stresses the role of transaminases as chief biomarkers during exposure to chemicals leading to metabolic stress. AST and ALT are chief indicators in liver function tests, as AST is synthesized by liver hepatocyte and mostly found in liver and heart, while ALT primarily found in liver and kidney. ${ }^{18}$ Lactate dehydrogenase (LDH), an iso-enzyme important in glycolysis, is a principle indicator of organ and tissue damage. Table 1 presents the elevated activity of lactate dehydrogenase on exposure of catla fish to lithium nitrate. The rise in $\mathrm{LDH}$ can be ascribed to augmented glycolysis during metabolic stress. Onset of anoxia is also a important parameter for elevated LDH activity. Incidence of anaerobic condition due to chemical toxicity is also reported during rise of $\mathrm{LDH}$ activity. ${ }^{19}$

Table 1: Alterations in the biochemical variables of $C$ catla exposed to Lithium nitrate (0.5ppm).

\begin{tabular}{|c|c|c|c|c|c|c|c|c|}
\hline \multirow{3}{*}{$\begin{array}{c}\text { Biochemical } \\
\text { variables }\end{array}$} & \multicolumn{8}{|c|}{ Exposure duration (in h) $0.5 \mathrm{ppm}$} \\
\hline & \multicolumn{2}{|c|}{24} & \multicolumn{2}{|c|}{48} & \multicolumn{2}{|c|}{72} & \multicolumn{2}{|c|}{96} \\
\hline & $\mathrm{C}$ & $E$ & C & $E$ & $\mathrm{C}$ & $\mathrm{E}$ & $\mathrm{C}$ & $E$ \\
\hline $\begin{array}{c}\text { Glucose } \\
(\mathrm{mmol} / \mathrm{L})\end{array}$ & $\begin{array}{c}3.34 \\
\pm 0.35\end{array}$ & $\begin{array}{c}7.25 \\
\pm 0.16^{\star}\end{array}$ & $\begin{array}{c}4.06 \\
\pm 0.18\end{array}$ & $\begin{array}{c}22.51 \\
\pm 2.44^{*}\end{array}$ & $\begin{array}{c}4.12 \\
\pm 0.66\end{array}$ & $\begin{array}{c}27.45 \\
\pm 0.34^{\star}\end{array}$ & $\begin{array}{c}4.23 \\
\pm 0.29\end{array}$ & $\begin{array}{c}28.11 \\
\pm 0.16^{*}\end{array}$ \\
\hline $\begin{array}{l}\text { Protein } \\
(\mathrm{g} / \mathrm{L})\end{array}$ & $\begin{array}{l}15.18 \\
\pm 0.53\end{array}$ & $\begin{array}{c}20.19 \\
\pm 1.64^{*}\end{array}$ & $\begin{array}{l}15.66 \\
\pm 0.46\end{array}$ & $\begin{array}{c}19.51 \\
\pm 0.52^{*}\end{array}$ & $\begin{array}{l}15.71 \\
\pm 0.06\end{array}$ & $\begin{array}{c}15.43 \\
\pm 0.17^{\star}\end{array}$ & $\begin{array}{l}15.32 \\
\pm 0.38\end{array}$ & $\begin{array}{c}11.68 \\
\pm 0.12^{*}\end{array}$ \\
\hline $\begin{array}{c}\mathrm{LDH} \\
(\mathrm{IU} / \mathrm{L})\end{array}$ & $\begin{array}{c}4.77 \\
\pm 0.14\end{array}$ & $\begin{array}{c}6.15 \\
\pm 0.47^{\star}\end{array}$ & $\begin{array}{c}4.35 \\
\pm 0.13\end{array}$ & $\begin{array}{c}6.46 \\
\pm 0.18^{*}\end{array}$ & $\begin{array}{c}4.38 \\
\pm 0.27\end{array}$ & $\begin{array}{c}6.86 \\
\pm 0.08^{*}\end{array}$ & $\begin{array}{c}4.53 \\
\pm 0.02\end{array}$ & $\begin{array}{c}6.74 \\
\pm 0.27^{*}\end{array}$ \\
\hline $\begin{array}{c}\text { AST } \\
(\mathrm{IU} / \mathrm{L})\end{array}$ & $\begin{array}{l}17.39 \\
\pm 0.14\end{array}$ & $\begin{array}{c}21.02 \\
\pm 0.48^{*}\end{array}$ & $\begin{array}{l}17.44 \\
\pm 0.65\end{array}$ & $\begin{array}{c}22.47 \\
\pm 0.53^{*}\end{array}$ & $\begin{array}{l}17.87 \\
\pm 0.33\end{array}$ & $\begin{array}{c}25.29 \\
\pm 1.65^{\star}\end{array}$ & $\begin{array}{l}17.36 \\
\pm 0.78\end{array}$ & $\begin{array}{r}27.19 \\
\pm 1.63^{*}\end{array}$ \\
\hline $\begin{array}{c}\text { ALT } \\
\text { (IU/L) }\end{array}$ & $\begin{array}{l}21.58 \\
\pm 0.14\end{array}$ & $\begin{array}{c}25.69 \\
\pm 0.73^{*}\end{array}$ & $\begin{array}{l}21.07 \\
\pm 0.56\end{array}$ & $\begin{array}{c}26.12 \\
\pm 0.22^{*}\end{array}$ & $\begin{array}{l}19.95 \\
\pm 0.48\end{array}$ & $\begin{array}{c}29.05 \\
\pm 0.77^{*}\end{array}$ & $\begin{array}{c}28.94 \pm \\
0.91\end{array}$ & $\begin{array}{c}29.85 \\
\pm 0.44^{*}\end{array}$ \\
\hline
\end{tabular}

All values are expressed as mean $\pm \mathrm{SE}$ of three individual samples, ${ }^{\star} P<0.05$ is significant. 
Figure 1 shows rise in glutamate levels in lithium nitrate exposed fish $(14.07 \pm 0.13)$ in comparison to the un-treated groups $(12.3 \pm 0.22)$ on $4^{\text {th }}$ day. This observation can be linked to exotoxicity and unwarranted generation of glutamate, which leads to nerve cell damage and death. The elevated glutamate levels changes brain physicochemical milieu following activation of the glutamate receptors by allow soaring concentration of calcium ions to permeate the cell. ${ }^{20}$

Formation of reactive oxygen species (ROS) leads to oxidative stress and disturbs the biological pathways by disturbing homeostasis, consequently disturbing the equilibrium of detoxification process of reactive oxygen species. ${ }^{21}$ To scavenge the disproportionate production of free radicals, cells provide the enzymatic and non-enzymatic system responses. The pro-oxidant properties of chemicals are the basis of free radical formation during mitochondrial respiration and therefore triggering NADPH-like enzymes. Superoxide dismutase (SOD) and catalase (CAT) are chief antioxidant enzymes which scavenge free radicals generated through metabolism and physiological processes. Superoxide dismutase is reported to be the major and instantaneous response to oxidative stress in living system. ${ }^{22}$ In this study the data in Table 2 exhibit declining SOD and CAT parameters in treated groups in comparison to the un-treated groups. This is because, the formation $\mathrm{O}_{2}$ and its conversion to $\mathrm{H}_{2} \mathrm{O}_{2}$ which further bring about oxidation of cysteine in the antioxidant enzyme structure, thus underlining the toxicity of lithium nitrate.
Lipid peroxidation (LPO) is the chief reason for disruption of cell structure and function by free radicals. ${ }^{23}$ The lipid peroxidation process is usually determined by the measurement of malondialdehyde (MDA) levels, which is one among the end products of breakdown of lipids owing to peroxidation. ${ }^{22}$ The present results in C. catla, recommend that liver is probably one of the most affected organ, as there is noticeable rise in MDA content in exposed fish compared to the non exposed fish (Table 2).

The result indicates that the existing cellular defense mechanism failed to ward off the oxidative damage. . $3,24^{2}$

The above mentioned reports imply bioaccumulation of lithium nitrate. The study for the first time, reports that the release of lithium nitrate to the aquatic ecosystem cause harmful effects on fish and human population

\section{CONFLICTS OF INTEREST}

The authors declare that there is no conflicts of interest with respect to the publication of this manuscript.

\section{REFERENCES}

1. Perva S, Swamy K, Chandrashekar N, Subramanian R, Sukumaran S, Chandra SP S. Physio-biochemical responses of Indian major carp Catla catla upon subchronic exposure to tin oxide nanoparticles. Egyptian Journal of Aquatic Biology and Fisheries. 2020 Jul 1;24(4):509-20. doi.org/10.21608/ejabf.2020.102144

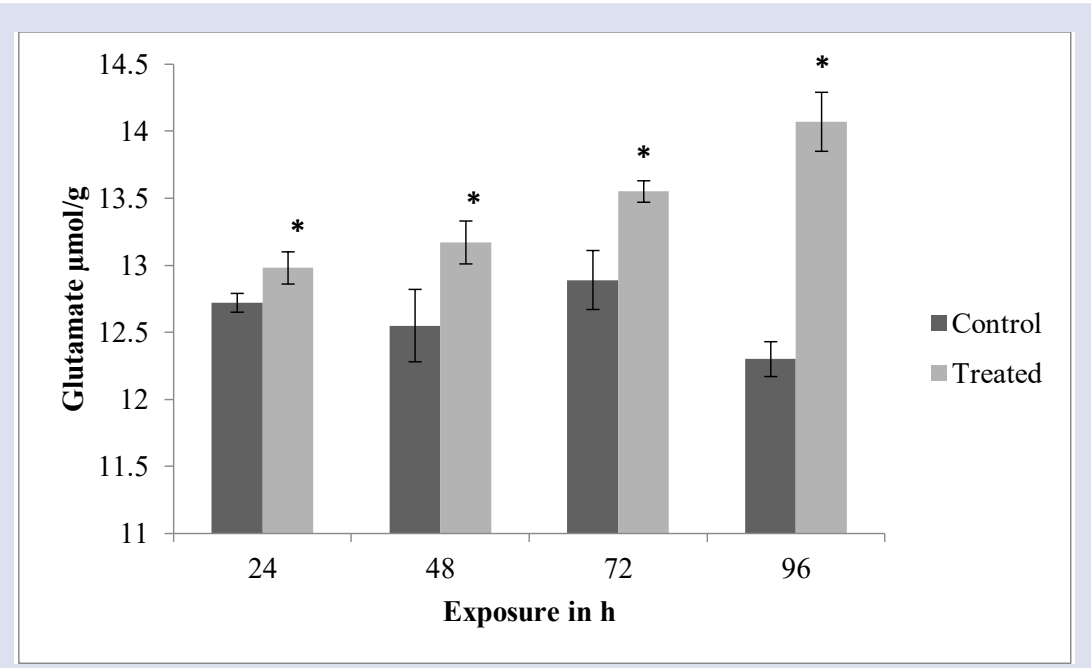

Figure 1: Alterations in the brain glutamate level of $C$. catla exposed to Lithium nitrate (0.5ppm).

All values are expressed as mean \pm SE of three individual samples, ${ }^{*} P<0.05$ is significant

Table 2: Alterations in the ROS variables of $C$ catla exposed to Lithium nitrate (0.5ppm).

\begin{tabular}{|c|c|c|c|c|c|c|c|c|}
\hline \multirow{3}{*}{$\begin{array}{c}\text { ROS } \\
\text { variables }\end{array}$} & \multicolumn{8}{|c|}{ Exposure duration (in h) $0.5 \mathrm{ppm}$} \\
\hline & \multicolumn{2}{|c|}{24} & \multicolumn{2}{|c|}{48} & \multicolumn{2}{|c|}{72} & \multicolumn{2}{|c|}{96} \\
\hline & C & $\mathrm{E}$ & C & $\mathrm{E}$ & C & $\mathrm{E}$ & C & $E$ \\
\hline $\begin{array}{c}\text { SOD } \\
\text { (U/mL protein) }\end{array}$ & $\begin{array}{c}4.72 \\
\pm 0.42\end{array}$ & $\begin{array}{l}4.04^{*} \\
\pm 0.59\end{array}$ & $\begin{array}{c}4.55 \\
\pm 0.07\end{array}$ & $\begin{array}{l}3.67^{\star} \\
\pm 0.44\end{array}$ & $\begin{array}{c}4.83 \\
\pm 0.58\end{array}$ & $\begin{array}{l}3.21^{\star} \\
\pm 0.27\end{array}$ & $\begin{array}{c}4.14 \\
\pm 0.79\end{array}$ & $\begin{array}{c}3.07 \\
\pm 0.50\end{array}$ \\
\hline $\begin{array}{c}\text { CAT } \\
(\mu \mathrm{mol} / \mathrm{ml} \text { protein } / \mathrm{min})\end{array}$ & $\begin{array}{c}2.79 \\
\pm 0.25\end{array}$ & $\begin{array}{c}2.22 \\
\pm 0.15^{\star}\end{array}$ & $\begin{array}{c}2.18 \\
\pm 1.12\end{array}$ & $\begin{array}{c}1.96 \\
\pm 0.16^{*}\end{array}$ & $\begin{array}{c}2.93 \\
\pm 0.35\end{array}$ & $\begin{array}{c}1.65 \\
\pm 0.25^{\star}\end{array}$ & $\begin{array}{c}2.02 \\
\pm 0.56\end{array}$ & $\begin{array}{r}1.49 \\
\pm 0.05^{*}\end{array}$ \\
\hline nmol of MDA/mg protein) & $\begin{array}{c}3.59 \\
\pm 0.70\end{array}$ & $\begin{array}{c}3.78 \\
\pm 0.54^{\star}\end{array}$ & $\begin{array}{c}3.17 \\
\pm 0.93\end{array}$ & $\begin{array}{c}4.01 \\
\pm 0.18^{*}\end{array}$ & $\begin{array}{c}3.32 \\
\pm 0.09\end{array}$ & $\begin{array}{c}4.65 \\
\pm 0.08^{*}\end{array}$ & $\begin{array}{c}3.76 \\
\pm 0.41\end{array}$ & $\begin{array}{c}4.98 \\
\pm 0.33^{\star}\end{array}$ \\
\hline
\end{tabular}

All values are expressed as mean $\pm \mathrm{SE}$ of three individual samples, ${ }^{\star} P<0.05$ is significant. 
2. Rashmi N, RanjithaT, Sharath Chandra SP. 2019. Chromium and their derivatives causes physiological and biochemical modifications in diverse fish models: A Review. Biomed Pharmacol J 12 (4): 2049-2053. doi.org/10.13005/bpj/1838

3. Amdur MO, Dull J, Klaassen CD. Toxicology: 1991. The Basic Science of Poison. Pergamon Press.

4. Bernet D, Schmidt H, Meier W, Burkhardt-Hol P, Wahli T. 1991. Histopathology in fish: proposal for a protocol to assess aquatic pollution. J Fish Dis 22:25-34. doi.org/10.1046/j.1365-2761.1999.00134.x

5. Chen Cy, Folt $\mathrm{Cl}$. 2000. Bioaccumulation and diminution of arsenic and lead in a freshwater food web. Environ Sci Technol 34:3878-3884. doi.org/10.1021/ es991070c

6. Reda Fa, Bakr Ahmad M, Kamel Sayed A, Sheba, Doaa R. Abdul-Haleem. 2010 A mathematical model for estimating the LC50 or LD50 among an in seet life cycle Egypt. Acad. J Bio Sci 32:75-81. doi.org/10.21608/eajbsa.2010.15191

7. Li Zh, Zlabek V, Velisek J, Grabic R, Machova J, Randak T. 2010. Modulation of antioxidant defence system in brain of rainbow trout (Oncorhynchus mykiss) after chronic carbamazepine treatment. Comp Biochem Physiol C Toxicol Pharmacol 31:137-41. doi.org/10.1016/j.cbpc.2009.09.006

8. Cooper Gr, Mcdaniel V. 1970.Standard methods of clinical chemistry. Academic, New York.

9. Lowry Oh, Rosebrough Nj, Farr Al, Randall Rj. 1951. Protein measurement with the Folin phenol reagent. J Biol chem. 193(1):265-75.

10. Reitman, S., Franckel, S. 1957. A colorimetric method for the determination of serum glutamic oxalo acetic and glutamic pyruvic transaminase. Am. J. Clin Pathol 28:56-63. doi.org/10.1093/ajcp/28.1.56

11. Das, K.; Samanta, L.; Chainy, G.B.N. 2000. A modified spectrophotometric assay of superoxide dismutase using nitrite formation by superoxide radicals. Indian J. Biochem. Biophys 37: 201-204.

12. Goth L. 1991. A simple method for determination of serum catalase activity and revision of reference range. Clin Chim Acta 15, 196(2-3):143-51. doi. org/10.1016/0009-8981(91)90067-M

13. Buege JA, Aust SD. 1978. Microsomal lipid peroxidation. Methods Enzymol 31 52: 302-10. https://doi.org/10.1016/S0076-6879(78)52032-6

14. RajuTR, Kutty BM, SathyaprabhaTN, Shankarnarayana Rao BS. 2004. Brain and behavior 134-138.
15. Klaper R, Arndt D, Setyowati K, Chen J And Goetz F. 2010. Functionalization impacts the effects of carbon nanotubes on the immune system of rainbow trout, Oncorhynchus mykiss. Aquat Toxicol 100:211-217. doi.org/10.1016/j. aquatox.2010.07.023

16. Chen PJ, Su Ch, Tseng CY, Tan SW, Cheng CH. 2011. Toxicity assessments of nanoscale zerovalent iron and its oxidation products in medaka (Oryzias latipes) fish. Mar Pollut Bull 31, 63(5): 339-46. doi.org/10.1016/j.marpolbul.2011.02.045

17. B.D. Abhijith, M. Ramesh, R.K. Poopal. 2016. Responses of metabolic and antioxidant enzymatic activities in gill, liver and plasma of Catla catla during methyl parathion exposure, The Journal of Basic \& Applied Zoology 77: 31-40. doi.org/10.1016/j.jobaz.2015.11.002

18. Rao, V.J.2006. Sublethal effects of an organophosphorus insecticide (RPR II) on biochemical parameters of tilapia, Oreochromis mossambicus. Comp. Biochem. Physiol C 143 (4):492-498. doi.org/10.1016/j.cbpc.2006.05.001

19. Manev H, Favaron MA, Guidotti AL, Costa ER. 1989. Delayed increase of Ca2+ influx elicited by glutamate: role in neuronal death. Mol Pharmacol (1):106-12.

20. Manke, A., Wang, L., \& Rojanasakul, Y. 2013.Mechanisms of nanoparticleinduced oxidative stress and toxicity. BioMedical Research International 916942. doi.org/10.1155/2013/942916

21. Winston, G.W., Di Giulio, R.T. 1993. Prooxidant and antioxidant mechanisms in aquatic organisms. Aquat. Toxicol 19: 137-161. doi.org/10.1016/0166445X(91)90033-6

22. Sharath Chandra SP, Sukumaran S. 2020. Magnesium chloride impairs physiobiochemical and neurochemical responses in Cirrhinus mrigala (Hamilton, 1822) upon short term exposure. Biointerface Research in Applied Chemistry 2020. 10(1):4934-8. doi.org/10.33263/BRIAC101.934938

23. Chandra, S. P., Puneeth, H. R., Mahadimane, P. V., \&Sharada, A. C. 2017 Biochemical Evaluation of Cordia dichotoma Seed Extracts. Advanced Science Letters 23(3): 1823-1825. doi.org/10.1166/asl.2017.8514

24. Puneeth, H. R., \& Chandra, S. S. P. 2020. A review on potential therapeutic properties of Pomegranate (Punica granatum L.). Plant Science Today7(1):9-16. doi.org/10.14719/pst.2020.7.1.619

25. Chandra, S., \& Sukumaran, S. 2020. Physiological, Biochemical and Neurochemical responses of Cirrhinus mrigala upon short term exposure to Cerium oxide. International Journal of Aquatic Biology 7(6):368-373.

\section{GRAPHICAL ABSTRACT}

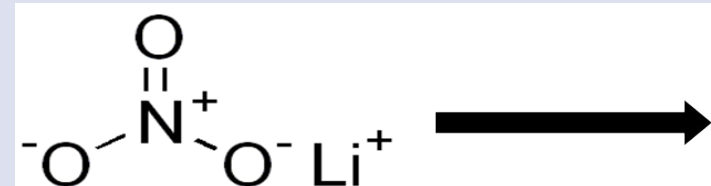

Lithium nitrate

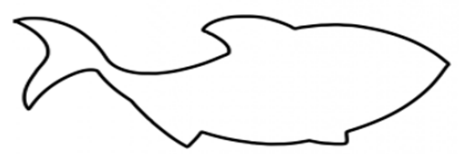

Catla catla

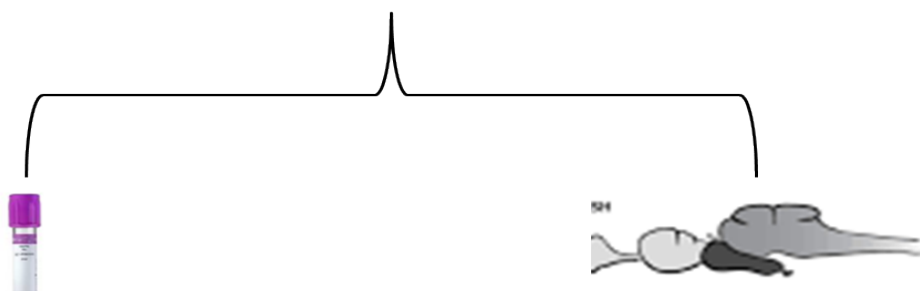

Glutamate analysis

Biochemical \&, oxidative stress 


\section{ABOUT AUTHORS}

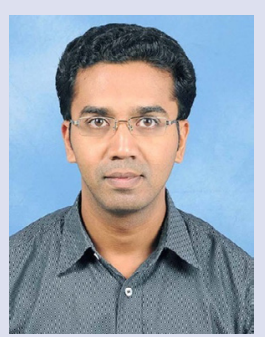

Dr. S. Jagadeep Chandra works as an Assistant Professor in the Department of Microbiology, School of Life Sciences, JSS academy of Higher education and research, Mysuru. He obtained his PhD from University of Mysore in Microbiology. He has served has the Regional director for KSOU previously. His research interests are toxicology and folk medicinal plants.

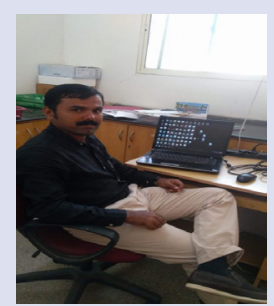

Dr. Naganagouda. V. Kote is an Assistant Professor of Biochemistry in the PG department of studies in Biochemistry, Maharani's Science College for Women, Bengaluru. He has more than 10 years of teaching and research experience. He has served as the Principal investigator for project funded by UGC. Dr. Gouda is a Gold Medalist in M.Sc Biochemistry. He has to his credit several publications in International peer reviewed journals.

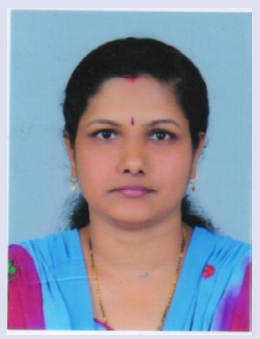

Dr. S. Sandya holds Masters and PhD degree in Biochemistry. Currently she is working as Sr.Scientific officer in the Department of Inorganic and Physical chemistry, Indian Institute of Science, Bengaluru, India. Her research interest includes cellular biochemistry associated to inflammation, extra cellular matrix modulatory effects, anti- inflammatory agents and antioxidants. She has served as Principal Investigator for projects funded by DST, India.

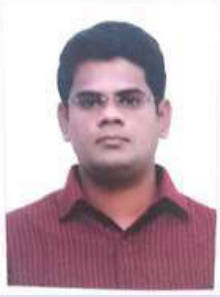

Dr. Sharath Chandra SP is an Assistant Professor of Biochemistry in Government Science College, Hassan, India. He has more than 12 years of research experience with publications in peer reviewed International journals. He is recipient of International young scientist awards from International science associations like FAOBMB, ISN.

Cite this article: Chandra SJ, Kote NV, Sandya S, Sharath CSP. Lithium Nitrate Induced Biochemical Modifications in catla catla upon Short Term Exposure. Pharmacogn J. 2020;12(6)Suppl:1705-9. 